\title{
School Banking, Its Trend and Nexus with Profitability in Bangladesh
}

\author{
Md. Abdullah Al Mamun \\ Department of Business Administration, Pabna University of Science and Technology, Pabna, Bangladesh \\ Email address: \\ mamunfin38@gmail.com \\ To cite this article: \\ Md. Abdullah Al Mamun. School Banking, Its Trend and Nexus with Profitability in Bangladesh. International Journal of Finance and \\ Banking Research. Vol. 7, No. 1, 2021, pp. 21-28. doi: 10.11648/j.ijfbr.20210701.13
}

Received: February 3, 2021; Accepted: February 15, 2021; Published: March 10, 2021

\begin{abstract}
This work attempts to observe the current state of school banking, its trend and its association with profitability. Data from secondary sources have been collected for the period of 10-years from 2011 to 2020 to achieve the goals. The data have been collected, tabulated, categorized, coordinated and performed the relevant calculation of to fulfill the purpose. With the assistance of MS Office Excel and IBM SPSS-21, tabular presentation, graphical analysis, percentage, correlation, and simple linear regressions have been used to analyze data. Independent variables are known to be the volume of deposits in the school bank account. Return on assets (ROA) and return on equity (ROE) are chosen as profitability yardstick and used as a dependent variable for regression analysis. The results of the research have shown an increasing trend of account opening during the time and collection of deposits from these accounts. Between 2011 to 2020, the amount of school bank deposits compared to banks' overall deposits also increased from 0.01 percent to 0.16 percent. The assessment of the correlation showed that there was a strong positive association between the number of accounts opened and the sum deposits in those accounts. It also found that there was a relatively high negative relationship between the volume of deposits in school bank accounts and the return on equity and the return on assets. The output of the regression also clearly shows that school banking (amount of deposits) has a negative relationship with return on equity and return on total asset. The analysis is carried out on the basis of secondary data. However it is not possible to judge validity and reliability.
\end{abstract}

Keywords: School, Banking, Accounts, Deposits and Profitability

\section{Introduction}

Banks' key functions are mainly categorized into two parts, i.e. the collection of deposits from the surplus unit and the provision to the deficit unit of the collected funds through the disbursement of loans. Usually, banks obtain deposits from the mass population of the country through financial inclusion, irrespective of age, class, social status, religion, etc. [5]. The bank is a profit hunting institution. The profitability of the banks are relies on their lending and investing. The health of banking industry typically depends on amount deposit available for them. Saving is the portion of disposable income that is sacrificed from the present consumption. The disposable income is after-tax income available for spending. Generally the higher the income, the more the saving's. The lending and investment activities are heavily depends on availability of funds. The deposit is main sources for fund for banking business. There are different types of deposits accounts. The saving account, current account and term deposit account by which banks are collecting deposits. Due age restriction age below 18 year cannot open a bank account in Bangladesh independently [17]. The people age below 18 are defined as minor by law. Of the minors some a lion portions of them are students. The students are the future citizen of the country. They are out of the main flow of the financial system. In order to include them in the financial flow and development of saving habits in the early age, Bangladesh bank introduces new banking idea for the student is called as school banking. School banking account is a student-named savings deposit account to be jointly managed in conjunction with the signature of the guardian who may be the account nominee [1]. Although, like other deposit schemes, it did not fulfill its expectations because of the lack of publicity school banking scheme. The service for students began to be launched slowly but gradually by many banks. For many school children, parents, and teachers, the concept of school 
banking was very new. But all over the country, the program was already gaining popularity. At the time, it was possible to open a school banking account for students aged 11 to under 18 years old. Thus, the campaign of school banking has to be emphasized by Bangladesh Bank and other commercial banks. Bangladesh Bank, Bangladesh's central bank, directed all scheduled banks on 2 November 2010 to implement a student financial inclusion policy circular no. 12 under the name of School Banking by BRPD (Banking Regulation and Policy Department) [10]. Hossen [8] also represented that banks have introduced clients to strike up their deposit with various types of products in order to improve bank business and encourage clients to be introduced to build up their capital to protect the imminent destruction miseries. The School Banking Scheme is a distinct product, but it is becoming more popular in aimed at encouraging savings and create a savings mindset for school-going students with an enticing interest rate [7]. Through this scheme, most students can raise capital for their future, and this bank not only utilizes recurring deposits, but also plays a social role in the country. Alom [3] clarified that school banking offers banking services to students so that they can initiate savings, engage in banking activities, participate and contribute to economic activities by savings. He also focused on historical evidence on the amount of accounts and money deposited in several banks under the school banking scheme (rural and urban areas). He also strongly believed that school banking would very soon have to be an integral part of everyday banking services. From the literature, if we compare the account savings of the urban area with the rural area, then we see that the school banking program performs better in urban than rural areas [6]. For this reason, in urban and rural areas, we can get an idea of financial literacy among children. We may also conclude that children are becoming more financially educated in urban areas than in rural areas. Bangladesh, however, is a rural-based nation. Without the growth of rural areas, economic development will not be feasible [9]. Governments, the Bangladesh Bank, and other banks should therefore work more on the rural school banking program.

\section{Literature Review}

A research on School Banking in Bangladesh was completed by Ahmed and Maksuda [2] A Study on Sustainability. The aim of the study was to understand the student's financial knowledge, attitude and socialization, and the guardian's financial knowledge for school banking sustainability. To achieve the objective data of 50 schools, of which 1,515 students and 1,137 parents gathered by questionnaire from primary, junior high school and high school. They discovered that students learn more from school and parents about money, with a focus on saving. Parents believe that it is necessary for children to save and use structured financial institutions, although students and their parents or guardians are likely to have different ideas about what saving entails. Around half the students talk about money to their parents or guardians at least some of the time, while the other half talk about it very rarely or never.

The title of an article on the overview of the school banking program was published in Islam, Rabbany and Sadia [14] its difficulties, opportunities and acceptability. The aims of the study were to evaluate Bangladesh's level of understanding of the concept of school banking, roles, barriers, acceptance of customers and potential prospects. To attain the targets, data were collected from both primary and secondary sources. A systematic questionnaire for bankers, depositors and non-depositors was used to collect the primary data. From published journals, directories and newspapers, secondary data were also obtained. The collected data was analyzed with the assistance of tabular analysis, graphical presentation, percentage and pattern of account opening. Most of the students were unaware of the school's banking activities and the benefits and were unable to open an account. Most of the guardian also were unaware of school banking and benefits and reluctant to open account.

Mondol, Khan and Hossain [12] conducted a study titled School Banking: A New Phenomenon of Banking Operation in Bangladesh. The goal of the research was to examine school banking practices in Bangladesh. The data from various secondary sources accumulated by them were used to achieve the objectives. To accomplish the objectives, they applied content analysis by tabular presentation, graphical presentation, and percentage and pattern of the relevant variables. They discovered that school banking was gaining popularity at an early age and showed a rising trend in terms of account opening and account deposits.

A report on contemporary financial services was published in Bangladesh by Sarker \& Foysal [15] a case study of school banking. The purpose of the study was to assess the efficacy of Bangladeshi school banking. Data from primary and secondary sources was gathered to achieve the target. Using a formal questionnaire, primary data were obtained. From published journals, websites and newspapers, secondary data were also obtained. The collected data was analyzed using tabular analysis, graphical presentation, percentage, deposit trend, and account opening. The trend in school banking has increased rapidly during the time since its inception because of lucrative opportunities and benefits. Both the number of accounts and the amount of deposits grew during the study period.

Mahmud [11] has been completed a project on the Financial Literacy Scope through School Banking: The Bangladesh Case. The primary objective of the project was to identify the scope of financial literacy from a possible point of view as part of financial inclusion through school banking. He obtained data from both the main and secondary sources in order to achieve the goal. The primary information was obtained from a questionnaire. Accumulated secondary data from the annual report of the Bangladesh bank, quarterly report, financial inclusion department report, official records and websites. Using SPSS-22, he analyzed the data. He discovered that financial literacy and school banking had a relationship. By giving them some special benefits, school banking attracts school-going children and makes sense of the importance of 
saving, money management, banking activities that are involved in inclusive childhood finance, which does have a significant impact on the economy.

\subsection{The Research Goals}

The main objective of the research is to examine the current situation, pattern of school banking and the nexus with profitability. The objectives are:

Analyze the present state and pattern of school banking.

Identify the relationship between school banking and Bangladeshi banks' profitability.

\subsection{Hypothesis of the Study}

Hypothesis the current research are drawn on the basis of previous studies and specific objectives are as follows

$\mathrm{H}_{0}$ : There is no relationship between school banking and profitability

$\mathrm{H}_{\mathrm{a}}$ : There is a relationship between school banking and profitability

\section{Methodology}

The objectives of research are to analyze current status of school banking, its trend and relationship with profitability. To attain the objectives the data of school banking of all the commercial banks have been accumulated for the period of 10 years from 2011 to 2020 . The secondary data are collected from annual reports of all the commercial banks, Bangladesh bank quarterly financial inclusion report, quarterly report, half yearly report, annual report, newspapers, websites, articles and research papers etc. The first objective of this study is to be achieved through percentage, tabular presentation, graphical analysis and discussion. The second objective of the study is to be attained by the help statistical tools correlation and simple linear regression. In regression model the return on assets and return on equity have been selected dependent variable and amount of deposit in school banking account taken as independent variable. Return on assets and return equity of banking industry is used as profitability yardstick and amount of deposits in school banking account treated as school banking. Regression and correlation analysis have been applied to identify the relationship between school banking and profitability.

Regression model are

$$
R O A_{i t}=\beta_{0}+\beta_{1} D P_{i t}+e_{i t}
$$

$$
R O E_{i t}=\beta_{0}+\beta_{1} D P_{i t}+e_{i t}
$$

Where

ROA $=$ Return on assets

$\mathrm{ROE}=$ Return on equity

$\mathrm{DP}=$ Amount of deposit in school banking accounts for $\mathrm{i}$ firm in time $\mathrm{t}$ (school banking)

$\mathrm{e}_{\mathrm{it}}=$ error term

\section{Results and Discussions}

\subsection{Status of School Banking}

From December 2011 to June 2020, the comparative status of school banking in Bangladesh is shown in the following table (Table 1). Till to December 2011, the total number of 29080 accounts were opened by different type of banks. Of which 354 accounts were opened by state-owned commercial banks (SCB), 637 accounts by specialized banks (SB), 27830 accounts by private commercial banks (PCB), and 259 by foreign commercial banks (FCB) (table 1). The following pie chart (Figure 1) presents the status of school banking in Bangladesh. In 2011, 95.70 percent of accounts were opened by the private commercial banks (PCB), 1.22 percent by state owned commercial banks (SCB), 2.19 percent by specialized banks (SB), and 0.89 percent by foreign commercial banks (FCB) (Figure 1). The total number of school bank accounts up to June 2020 stood at 2431602. Till to June 2020, of which 608133 accounts were opened by state-owned commercial bank (SCB), 141855 by specialized banks (SB), 1678889 by private commercial banks (PCB) and 2725 by foreign commercial banks (FCB) (Table 1). Approximately 69.04 percent of accounts were opened by private commercial banks (PCB), 25.01 percent by state-owned commercial banks (SCB), and 5.83 percent by specialized banks (SB), and 0.11 percent by foreign commercial banks (FCB) (Figure 1). Though the percent of account opening reduced from 2011 to 2020 for private commercial bank and foreign commercial total number of account had also been increased. Percent of account opened by state owned commercial bank and specialized banks had increased from 1.22 to 25.01 percent, 2.19 to 5.83 percent respectively (Figure 1) These indicate that state owned commercial bank and specialized banks has enhanced their promotional activity. The total number of account increased from 29080 in 2011 to 2431602 in 2020. This shows that all the bank given tremendous effort in school banking and achieved admirable results.

Table 1. Number of school banking accounts for 2011 and 2020.

\begin{tabular}{lllll}
\hline $\begin{array}{l}\text { Bank } \\
\text { type }\end{array}$ & $\begin{array}{l}\text { number of accounts up to } \\
\text { December, 2011 }\end{array}$ & $\begin{array}{l}\text { Percentage of account up to } \\
\text { December, 2011 }\end{array}$ & $\begin{array}{l}\text { number of accounts up } \\
\text { to June, 2020 }\end{array}$ & $\begin{array}{l}\text { Percentage of account } \\
\text { up to June, 2020 }\end{array}$ \\
\hline (SCB) & 354 & 1.22 & 608133 & $\begin{array}{l}\text { changes in } \\
\text { account number }\end{array}$ \\
(SB) & 637 & 2.19 & 141855 & 607779 \\
(PCB) & 27,830 & 95.70 & 1678889 & 5.83 \\
(FCB) & 259 & 0.89 & 2725 & 69.04 \\
Total & 29080 & 100.00 & 2431602 & 0.11 \\
\hline
\end{tabular}

Source: Bangladesh bank quarterly report of financial inclusion from 2011 to 2020 [16] 

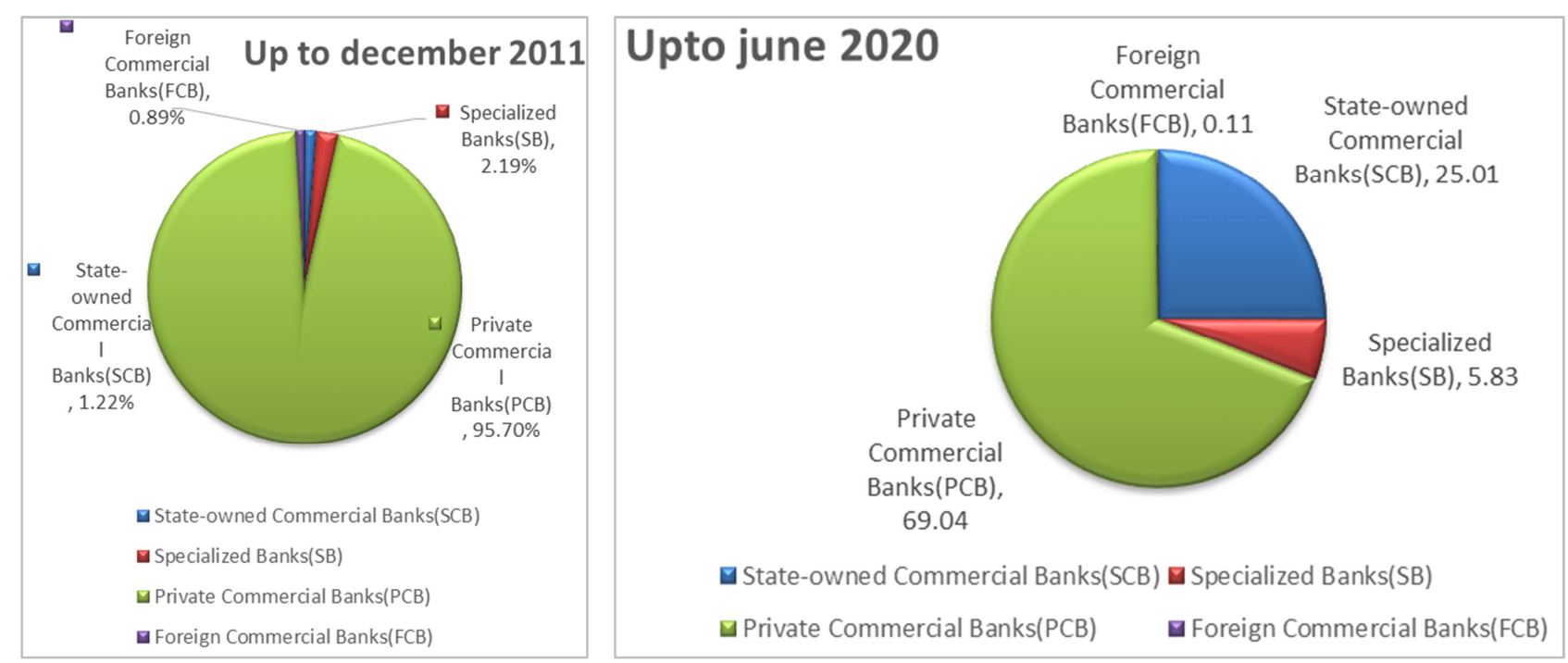

Source: Bangladesh bank quarterly report of financial inclusion from 2011 to 2020 .

Figure 1. Pie chart of comparative position of school banking 2011 to 2020.

\subsection{Deposit Mobilization}

The launch of the school banking program with the goal of promoting the habit of saving at an early age is one of the most important milestones in the financial inclusion initiatives of the Bangladesh Bank. The initiative exposes students under the age of 18 to banking facilities and new banking technologies. In November 2010, the Bangladesh Bank released a directive for banks to implement school banking. Initially 46 banks in Bangladesh had started its journey to the school banking. At the end of December 2011, accumulated deposits in the school banking accounts stood at Tk. 30.79 crores. Of that deposits, a lion portion Tk. 29.04 crores (in 94.32 percent) had been collected by the private commercial bank (PCB). The state-owned commercial banks (SCB), specialized bank (SB), foreign commercial bank (FCB) had also contributed in amassing deposits Tk. 1.16 crores (in 3.77 percent), Tk. 0.17 crores (in 0.55 percent), 0.42 crores (in 1.36 percent) respectively (Table 2). In 2011 the private commercial bank had given massive effort to financial inclusion. But now, of the 60 banks operating in Bangladesh so far, as many as 55 serve school banking services. The deposit of private commercial banks have reached from Tk. 29.04 crores (in 94.32 percent) to 1466.12 cores (in 83.17 percent) in June 2020. The contribution of deposits by state-owned commercial banks (SCB) Tk. 229.4 crores (in 13.01percent), specialized bank (SB) Tk. 41.26 crores (in 2.34percent), foreign commercial bank (FCB) tk. 26.04 crores (in 1.48 percent) (Table 2). The deposit of state-owned commercial banks (SCB), specialized bank (SB), and foreign commercial bank (FCB) have increased the both in amount and percent from 2011 to 2020 . So it can be concluded that deposit of the school bank has increased in absolute figure and in percent, demonstrate that school banking heading to towards the goal.

Table 2. Position of school banking deposits for 2011 and 2020.

\begin{tabular}{llllll}
\hline $\begin{array}{l}\text { Bank } \\
\text { type }\end{array}$ & $\begin{array}{l}\text { Amount of deposit } \\
\text { (In Crore Tk.) Up to } \\
\text { December, 2011 }\end{array}$ & $\begin{array}{l}\text { Percentage of deposit } \\
\text { share by categories banks } \\
\text { Up to December, 2011 }\end{array}$ & $\begin{array}{l}\text { Amount of deposit (In } \\
\text { Crore Tk.) Up to up to } \\
\text { June, 2020 }\end{array}$ & $\begin{array}{l}\text { Percentage of deposit share by } \\
\text { categories banks Up to June, } \\
\mathbf{2 0 2 0}\end{array}$ & $\begin{array}{l}\text { Increase in } \\
\text { deposit }\end{array}$ \\
\hline SCB & 1.16 & 3.77 & 229.4 & 13.01 & 228.24 \\
SB & 0.17 & 0.55 & 41.26 & 2.34 & 41.09 \\
PCB & 29.04 & 94.32 & 1466.12 & 83.17 & 1437.08 \\
FCB & 0.42 & 1.36 & 26.04 & 1.48 & 25.62 \\
Total & 30.79 & 100.00 & 1762.82 & 100.00 & 1732.03 \\
\hline
\end{tabular}

Source: Bangladesh bank quarterly report of financial inclusion from 2011 to 2020 [13].

\subsection{Contribution of Deposit Mobilization Through School Banking}

The following table (table 3 ) shows deposits mobilization through school banking. The table exhibits, total banking deposits, deposits of school banking accounts and percentage school banking deposit to total banking industry deposits.
Though the school banking started its journey 2011, it has already crossed ten years. In 2011 contribution of school banking deposit to the banking was 0.01 percent, after ten year it has reached to 0.16 percent. It seems at very little in amount but it is gradually increasing over the period. This is a good sign that implies a good habit introduce to the young 
generation. It can be concluded that deposits in school banking has been increasing from 2011 to 2020 .

Table 3. Percent of school banking deposits to total deposits from 2011 and 2020.

\begin{tabular}{lllll}
\hline Year & No. of account & School Banking deposit in billion Tk. & $\begin{array}{l}\text { Total deposit in billion } \\
\text { Tk. }\end{array}$ & $\begin{array}{l}\text { Percentage of School Banking deposit to total } \\
\text { deposit }\end{array}$ \\
\hline 2011 & 10590 & 0.3079 & 4115.9 & 0.01 \\
2012 & 67220 & 0.5318 & 4864.1 & 0.01 \\
2013 & 224719 & 1.2847 & 6105.3 & 0.02 \\
2014 & 639465 & 4.0729 & 6931.1 & 0.06 \\
2015 & 904652 & 6.8799 & 7939.8 & 0.09 \\
2016 & 1182179 & 8.8041 & 8994.1 & 0.10 \\
2017 & 1334338 & 11.28 & 9865.7 & 0.11 \\
2018 & 1539836 & 14.19 & 10815.4 & 0.13 \\
2019 & 1744651 & 15.166 & 11398.3 & 0.13 \\
2020 & 2431602 & 17.6282 & 10798.7 & 0.16 \\
\hline
\end{tabular}

Source: Bangladesh bank half yearly and annual reports from 2011 to 2020. [4].

\subsection{Trend of Number of School Banking Accounts and Deposits}

The following figure 2 shows the number of accounts and its trend over the period. From figure 2, it is observed that total number of accounts in school bank increase over the period from January to March 2014 to April to June 2020 with slight variation. The dashed line also exhibits the trend of accumulated accounts in school banking initiatives. The trend line shows upward over the period. With increase in account opening banking deposits increases. The following figure 3 exhibits the amount of deposit and its trend over the period from January to March 2014 to April to June 2020. With the increase of accounts in school bank, deposits increase over the period from January to March 2014 to April to June 2020 with little fluctuation. The trend line also shows increasing trend. Thus the figures indicate that increase in number of accounts also increase the amount of deposits. So, there is an association between school banking account opening and amount of deposits in those accounts.

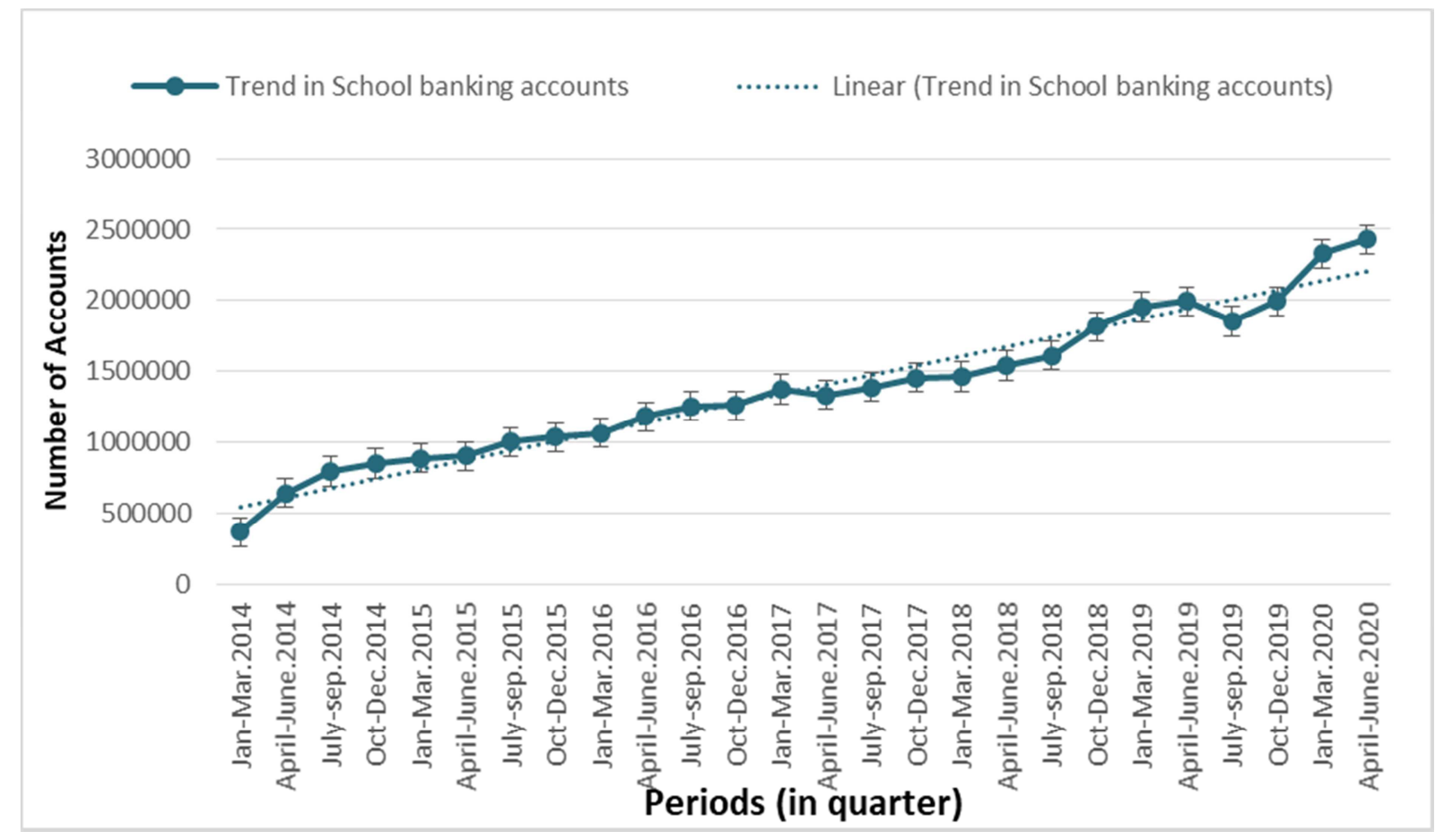

Figure 2. Trend in school banking accounts. 


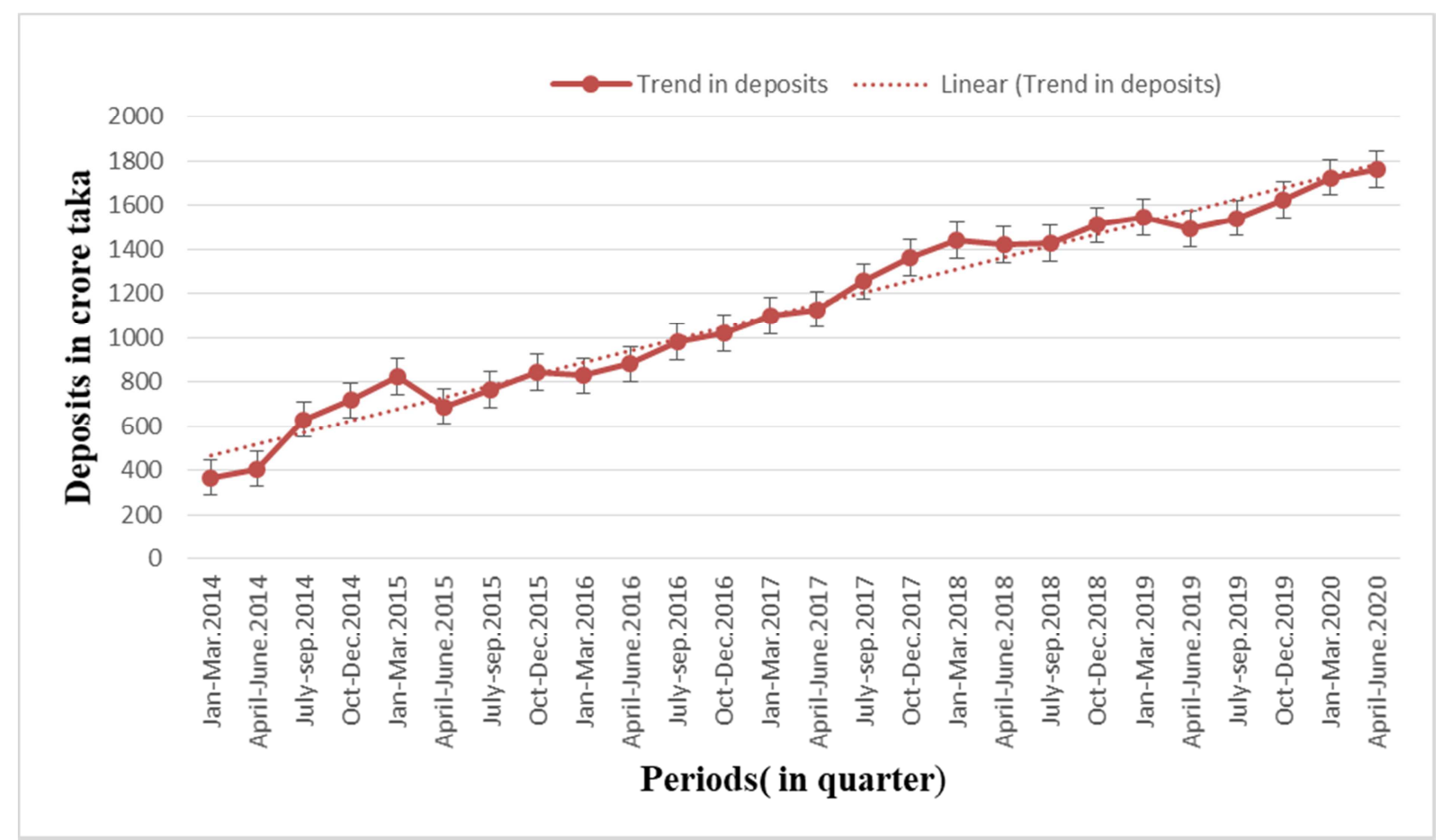

Figure 3. Trend of total deposits of School banking accounts.

\subsection{Correlations}

The following table 4 , demonstrates the connection between the dependent and independent variable. The association between the number of school banking accounts and the volume of deposits such account was 0.987 and significant at a level of significance of 0.000 percent. This suggests that the number of school banking accounts and the amount of deposits from those accounts had a positive relationship. But the correlation of numbers of school banking accounts and return on assets was -0.658 and significant at a probability of 0.039 . Similarly the value of correlation coefficient of numbers of school banking accounts and return on equity was -0.707 and significant at 0.020 level of significance. This means that the number of school banking accounts, the return on equity and the return on assets were negatively linked. The value correlation coefficient of return on asset and amount deposits in school banking accounts was -0.689 and that is significant at a probability of 0.028 . The correlation coefficient of amount deposits in school banking accounts and return on equity was -0.722 and which was significant at a probability of 0.018 . It could therefore be inferred that there was a positive relationship between the number of school banking accounts and deposit volume, but the relationship between profitability and school banking was negative.

Table 4. Correlation matrix of dependent variables and independent variables.

\begin{tabular}{|c|c|c|c|c|c|}
\hline & & NOA & DP & ROA & ROE \\
\hline NOA & $\begin{array}{l}\text { Pearson Correlation } \\
\text { Sig. (2-tailed) }\end{array}$ & 1 & & & \\
\hline DP & $\begin{array}{l}\text { Pearson Correlation } \\
\text { Sig. (2-tailed) }\end{array}$ & $\begin{array}{l}.987^{* *} \\
.000\end{array}$ & 1 & & \\
\hline ROA & $\begin{array}{l}\text { Pearson Correlation } \\
\text { Sig. (2-tailed) }\end{array}$ & $\begin{array}{l}-.658^{*} \\
.039\end{array}$ & $\begin{array}{l}-.689^{*} \\
.028\end{array}$ & 1 & \\
\hline ROE & $\begin{array}{l}\text { Pearson Correlation } \\
\text { Sig. (2-tailed) }\end{array}$ & $\begin{array}{l}-.707^{*} \\
.022\end{array}$ & $\begin{array}{l}-.722^{*} \\
.018\end{array}$ & $\begin{array}{l}.970^{* *} \\
.000\end{array}$ & 1 \\
\hline
\end{tabular}

Source: Analysis output SPSS-21

\subsection{Regression Results}

The upcoming section illustrates the result of regression equation (1). The following table (Table 6) shows that the F ratio of 7.227 is significant at a probability of 0.028 . The outcomes indicate that the model is statically significant. The table 5 also showing that the $r^{2}$ and adjusted $r^{2}$, are 0.475 and
0.409 respectively. This signify amount of deposits in school banking accounts accounted for $47.5 \%$ variability of the return of total assets. The value of the coefficient and it probability (Table 7) of amount of deposits in school banking accounts ( $\beta=-0.000373, p=0.000$. These imply that we have reject null hypothesis. The results implies that there appear to be a significant negative relationship between amounts of deposits 
in school banking account.

Table 5. Model Summary.

\begin{tabular}{llllll}
\hline Model & R & R Square & Adjusted R Square & Std. Error of the Estimate & Durbin-Watson \\
\hline 1 & $.689^{\text {a }}$ & .475 & .409 & .26552 & 2.107 \\
a. Predictors: (Constant), Amount of Deposits (School Banking) & & \\
b. Dependent Variable: ROA & & & \\
\hline
\end{tabular}

Source: Analysis output SPSS-21

Table 6. ANOVA ${ }^{a}$.

\begin{tabular}{lllllll}
\hline Model & & Sum of Squares & df & Mean Square & F & Sig. \\
\hline \multicolumn{1}{l}{1} & Regression & .509 & 1 & .509 & 7.227 & $.028^{\mathrm{b}}$ \\
& Residual & .564 & 8 & .070 & & \\
\multicolumn{2}{l}{$\begin{array}{l}\text { a. Dependent Variable: ROA } \\
\text { b. Predictors: (Constant), Amount of Deposits (School Banking) }\end{array}$} & 1.073 & 9 & & \\
\hline
\end{tabular}

Source: Analysis output SPSS-21

Table 7. Regression coefficients.

\begin{tabular}{lllllll}
\hline \multirow{2}{*}{ Model } & \multicolumn{2}{l}{ Unstandardized Coefficients } & Standardized Coefficients & \multirow{2}{*}{ t } & & \multirow{2}{*}{ Sig. } \\
\cline { 3 - 6 } & B & Std. Error & Beta & 7.167 & .000 \\
\multirow{2}{*}{1} & (Constant) & .997 & .139 & -.689 & -2.688 & .028 \\
\hline
\end{tabular}

Source: Analysis output SPSS-21

The following section illustrates the result of regression equation (2). The table (Table 9) exhibits that the $F$ ratio is 8.721 , which is significant at a probability of 0.018 . Indicating that the model is statistically significant. The table 8 also discloses that the $\mathrm{r}^{2}=0.522$ and adjusted $\mathrm{r}^{2}=0.462$, respectively. It indicates that deposits in school banking account explains
52.20 percent variability return on equity. The value of the coefficient and it probability (Table 10) are amount of deposits in school banking account $(\beta=-0.004, p=0.018)$. The results lead us to reject null hypothesis. This states that there is a negative relationship between amount of deposits in school banking account and return on equity.

Table 8. Model Summary.

\begin{tabular}{llllll}
\hline Model & R & R Square & Adjusted R Square & Std. Error of the Estimate & Durbin-Watson \\
\hline 1 & $.722^{\mathrm{a}}$ & .522 & .462 & 2.82421 & 2.223 \\
$\begin{array}{l}\text { a. Predictors: (Constant), Amount of Deposits (School Banking) } \\
\text { b. Dependent Variable: ROE }\end{array}$ & & & \\
\hline
\end{tabular}

Source: Analysis output SPSS-21

Table 9. ANOVA.

\begin{tabular}{lllllll}
\hline Model & & Sum of Squares & df & Mean Square & F & Sig. \\
\hline \multicolumn{1}{l}{1} & Regression & 69.561 & 1 & 69.561 & 8.721 & $.018^{\mathrm{b}}$ \\
& Residual & 63.809 & 8 & 7.976 & & \\
\multicolumn{2}{l}{ a. Dependent Variable: ROE } & 133.370 & 9 & & & \\
b. Predictors: (Constant), Amount of Deposits (School Banking) & & & \\
\hline
\end{tabular}

Source: Analysis output SPSS-21

Table 10. Regression coefficients.

\begin{tabular}{|c|c|c|c|c|c|c|}
\hline \multirow{2}{*}{\multicolumn{2}{|c|}{ Model }} & \multicolumn{2}{|c|}{ Unstandardized Coefficients } & \multirow{2}{*}{$\begin{array}{l}\text { Standardized Coefficients } \\
\text { Beta }\end{array}$} & \multirow[b]{2}{*}{$\mathbf{t}$} & \multirow{2}{*}{ Sig. } \\
\hline & & B & Std. Error & & & \\
\hline \multirow{2}{*}{1} & (Constant) & 12.363 & 1.480 & & 8.354 & .000 \\
\hline & Amount of Deposits (School Banking) & -.004 & .001 & -.722 & -2.953 & .018 \\
\hline
\end{tabular}

Source: Analysis output SPSS-21

\section{Conclusion}

The ultimate aim of the research is to examine the current status, pattern and profitability of school banking. In order to achieve the goals, data from secondary sources have been collected from 2011 to 2020 over a duration of ten years. The data have been accumulated from the quarterly financial inclusion report, quarterly report, half-yearly report, annual 
report of the Bangladesh Bank, journals, websites, etc. The findings showed a growing trend in opening school banking account over the duration and deposit collection of those accounts. The proportion of school bank deposits to overall deposits had increased from 2011 to 2020 by 0.01 percent to 0.16 percent. The correlation analysis confirmed that there was a positive association between the opening number of accounts and the volume deposit in those accounts. It also found that school banking and return on equity and return on assets had significant adverse relationships. The outcome of the regression also confirms that there is a negative relationship between school banking (the amount of deposits) and return on equity and return on asset. Although the relationship between school banking and bank profitability was negative, it can be concluded that school banking opens the doors among the young generation for banking business and banking habits.

\section{References}

[1] School banking (n.d.) Retrieved from http://www.krishibank.org.bd/bd/school-banking/.

[2] Ahmed, M. \& Maksuda, M. K., (2014). School Banking in Bangladesh: A Study on Sustainability. Thoughts on Banking and Finance, 3 (1), 65-75.

[3] Alam (2015), School Banking Created a New Era in the Banking Services in Bangladesh, BD Opinion, March 31, 2015. $\mathrm{http} / /$ www.bdopinion.com/2015/03/31/school-banking-created -a-new-era-in-the-banking-servics-in-bangladesh/.

[4] Bangladesh bank. Annual Report. (2011-2020). Retrieved from https://www.bb.org.bd/en/index.php/publication/publictn/0/2.

[5] Chowdhury, M. M. H., (2019) School Banking: Financial Inclusion at Childhood. Daily Sun. Retrieved January 30, 2021, from

https://www.dailysun.com/arcprint/details/408932/School-Ban king:-Financial-Inclusion-at-Childhood/2019-07-21.

[6] Chowdhury. M. M. H., (2019, July 17). School banking: Ensuring financial inclusion since childhood; The Financial Express. Retrieved January 26, 2021 from https://www.thefinancialexpress.com.bd/views/school-banki ng-ensuring-financial-inclusion-since-childhood-156337422 8.

[7] Hasan, M. (2020, July 14). Deposits from School Banking cross Tk1, 700cr. Dhaka tribune. Retrieved January 31, 2021 from https://www.dhakatribune.com/business/banks/2020/07/14/de posits-from-school-banking-cross-tk1-700cr.

[8] Hossen, M. M (2012), School Banking Scheme as a new Scheme for students, The Daily Frontier, September 22, 2012. $\mathrm{http} / /$ www.daily, frontier.com/Frontier/2012015109,School+Ba nking + Scheme + as $+a+$ new + Scheme + for + stu dents + .html.

[9] Kamruzzaman, M., (2018), Theory and practices of banking, ( $1^{\text {st }}$ Ed.) Abir Publications, Dhaka, 65-66.

[10] Maheswari, S. N., \& Maheswari, S. K., (2002), Banking Law and practices, $\left(11^{\text {th }}\right.$ ed). Kalyani Publishers, Delhi, 8-10.

[11] Mahmud, S. (2018). Scope of Financial Literacy through School Banking: The Case of Bangladesh. Retrieved from http://dspace.uiu.ac.bd/handle/52243/372

[12] Mondal, U., Hossain, M. S., \& Khan, M. A. M. (2015). School banking: a new idea of banking operation in Bangladesh. International Journal of Science and Research, 4 (11), 1926-1931.

[13] Quarterly Report on No-Frill Accounts (April-June). (2020). Financial Inclusion Department, Bangladesh Bank. https://www.bb.org.bd/en/index.php/publication/publictn/2/62.

[14] Rabbany, G. Islam. D. and Sadia. FT (2015). An Overview of School Banking Program: Its Problems, Prospects and Acceptability (A Case Study on Janata Bank Limited Shyamoli Corporate Branch). International Journal of Economics, Finance and Management Sciences, 3 (6), 685-694.

[15] Sarker, S. A., \& Foysal, T. Y. (2018). Contemporary Financial Services in Bangladesh: Case Study on School Banking. The cost and management, 46 (2).37-44.

[16] Sultana, M., Hossain, M. J., \& Banu, M. L. A. (2020). School Banking: Concept, Contribution and Prospect: The Perspective of Dutch Bangla Bank Ltd. (DBBL). European Journal of Business and Management, 12 (6), 70-81.

[17] Uddin, A. Z. (2020, March 18). School banking getting traction [Review of School banking getting traction]. The Daily Star. Retrieved January 25, 2021 from. https://www.thedailystar.net/business/news/school-banking-ge tting-traction-1882309. 